\title{
Posteriorly dislocated capsular tension ring leading to rhegmatogenous retinal detachment
}

\author{
Vineet Mutha, Nitesh Salunkhe, Vinod Kumar, Parijat Chandra
}

Dr Rajendra Prasad Centre for Ophthalmic Sciences, All India Institute of Medical Sciences, New Delhi, Delhi, India

\section{Correspondence to Dr Vineet Mutha, neetvinit@gmail.com}

Accepted 2 September 2017

\section{DESCRIPTION}

A 54-year-old woman presented with sudden diminution of vision in her left eye 4 months before. Medical history revealed that she underwent a phacoemulsification 1 year before in the left eye and 4 years before in the right eye. Snellen visual acuity in the right eye was $20 / 20$ while she was just able to count fingers at $1 \mathrm{~m}$ in the left eye. She had a divergent squint of 30 prism dioptres in the left eye. The right eye had a well-centred foldable posterior chamber intraocular lens (PCIOL) in the capsular bag, while the left eye had a rigid polymethyl methacrylate (PMMA) PCIOL in the sulcus with a large posterior capsular defect (figure 1A). On fundus examination of the left eye, we found a total rhegmatogenous retinal detachment with a large punched-out toxoplasma scar at the macula, three retinal horseshoe tears superonasally at the equator (figure 2B) and a dislocated capsular tension ring (CTR) with vitreous strands attached on both eyelets (figure 1B).

Swept source optical coherence tomography (Triton-Topcon, Tokyo, Japan) showed a punched-out macular scar (figure 1C). A standard 23-gauge pars plana vitrectomy with $360^{\circ}$ encircling band was performed in the left eye with induction of posterior vitreous detachment, followed by perfluorocarbon liquid injection and CTR removal via superior 20-gauge scleral entry in a rotatory fashion with end grasping forceps, followed by a nasal retinotomy, fluid air exchange, drainage of subretinal fluid and perfluorocarbon liquid, endolaser of breaks, and sulfur hexafluoride gas tamponade (figure $2 \mathrm{~A}-\mathrm{D}$ ). Visual acuity at

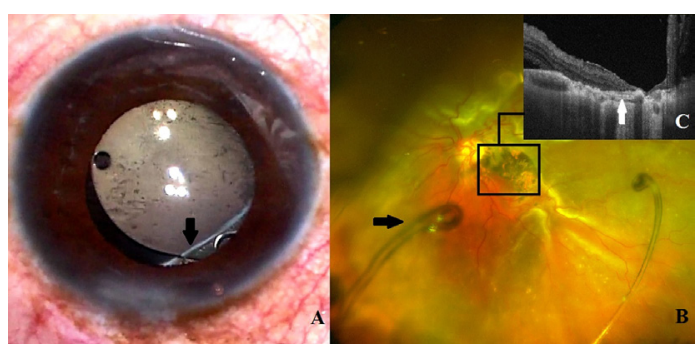

CrossMark

To cite: Mutha $\mathrm{V}_{\text {, }}$ Salunkhe N, Kumar V, et al. BMJ Case Rep Published Online First: [please include Day Month Year]. doi:10.1136/bcr-2017221634
Figure 1 Clinical picture of the anterior segment showing posterior chamber intraocular lens with posterior capsular defect (black arrow) in the left eye. (A) Ultrawide field pseudocolour retinography of the left eye. (B) Shows posteriorly dislocated capsular tension ring (black arrow) with a total rhegmatogenous retinal detachment and a macular scar: optical coherence tomography. (C) Scan captured via the macula shows punched-out macular scar (white arrow).

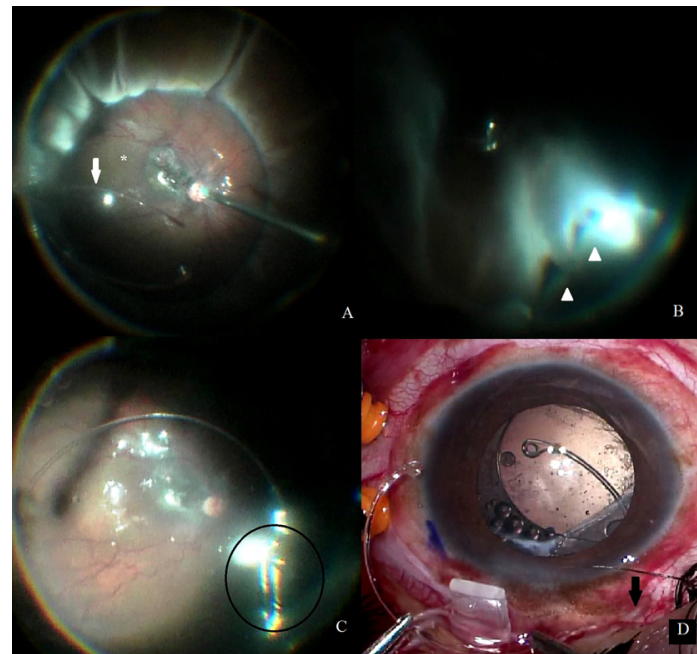

Figure 2 Intraoperative photographs of the left eye: (A) shows use of perfluorocarbon liquid-assisted removal of the capsular tension ring (CTR) (white arrow); (B) highlights the breaks causing retinal detachment (white arrowheads); (C) shows CTR held with end grasping forceps; and (D) demonstrates removal of CTR via superior scleral entry.

3 weeks postoperatively was finger counting at $4 \mathrm{~m}$ not further improving due to the aforementioned macular scar.

The concept of insertion of a ring to stabilise capsular bag during phacoemulsification was first given by Hara et al. ${ }^{1}$ In today's scenario, the principal use of CTR is to stabilise the capsular bag in cases of subluxated lens or zonular dialysis. However posterior capsular rupture and subluxation of more than six clock hours are well-known contraindications for CTR placement. A tear in the posterior capsule may expand during CTR insertion due to distension of the capsular bag. This may lead to migration of CTR to the posterior segment. Placement of an IOL in cases with posteriorly dislocated CTR should be avoided at the time of primary surgery as it closes the conduit for CTR removal via the anterior segment through a limbal wound, which is easier than removal via sclerotomy as in the present case scenario. There are very few previous case reports of surgical management of posteriorly dislocated CTR, with most of them describing removal via limbal wound in patients with aphakia. The presence of rhegmatogenous retinal detachment alongside posteriorly dislocated CTR in a patient with pseudophakia has not been described elsewhere. ${ }^{2-4}$ 


\section{Learning points}

- Placement of capsular tension ring (CTR) is contraindicated in cases with a defect in the posterior capsule due to high chances of its expansion and posterior migration of CTR.

- A case with posteriorly dislocated CTR should be promptly referred to a vitreoretina specialist so as to prevent a possible retinal detachment in the future.

Contributors All authors have significant contributions and fulfil the authorship criteria. VM: case selection. NS: surgical pictures. VK: manuscript preparation. PC: manuscript editing.

Competing interests None declared.

Patient consent Obtained.
Provenance and peer review Not commissioned; externally peer reviewed.

(c) BMJ Publishing Group Ltd (unless otherwise stated in the text of the article) 2017. All rights reserved. No commercial use is permitted unless otherwise expressly granted.

\section{REFERENCES}

1 Hara T, Hara T, Yamada Y. "Equator ring" for maintenance of the completely circular contour of the capsular bag equator after cataract removal. Ophthalmic Surg 1991;22:358-9.

2 Agarwal A, Trivedi RH, Jacob S, et al. Management of posteriorly dislocated capsular tension ring with vitrectomy using a "chandelier" illumination system. Clin Ophthalmol 2007;1:285-8.

3 Levy J, Klemperer I, Lifshitz T. Posteriorly dislocated capsular tension ring. Ophthalmic Surg Lasers Imaging 2005:36:416-8.

4 Lang Y, Fineberg E, Garzozi HJ. Vitrectomy to remove a posteriorly dislocated endocapsular tension ring. J Cataract Refract Surg 2001:27:474-6.

Copyright 2017 BMJ Publishing Group. All rights reserved. For permission to reuse any of this content visit

http://group.bmj.com/group/rights-licensing/permissions.

BMJ Case Report Fellows may re-use this article for personal use and teaching without any further permission.

Become a Fellow of BMJ Case Reports today and you can:

- Submit as many cases as you like

- Enjoy fast sympathetic peer review and rapid publication of accepted articles

- Access all the published articles

- Re-use any of the published material for personal use and teaching without further permission

For information on Institutional Fellowships contact consortiasales@bmjgroup.com

Visit casereports.bmj.com for more articles like this and to become a Fellow 